\title{
Chapter 15 \\ Prehistoric Speleological Exploration in the Cave of Aldène in Cesseras (Hérault, France): Human Footprint Paths and Lighting Management
}

\author{
Philippe Galant, Paul Ambert ${ }^{\dagger}$, and Albert Colomer ${ }^{\dagger}$
}

\begin{abstract}
Aldène Cave is a system of $9 \mathrm{~km}$ of extent, on four hydrogeological levels. Within the first two fossil levels, which comprise more than half of the system, many archaeological remains have been discovered. They represent a continuum of more than 350,000 years of human history. On the second level, we find the Paul Ambert gallery, discovered in 1948 by the Abbé Dominique Cathala. This gallery contains many human traces, with footprints and marks of torches that were brought into the cave. A recent geomorphological study of these elements concerned registration and systematic analysis of the lighting marks, as well as an initial determination of the footprints. This work confirmed the contemporaneousness and functional link of these archaeological remains. Lighting management could be determined precisely with the traces on the walls and the remains discovered on the floor in connection with the footprints. These data, investigated with a spatial approach in relation to the cave network, clarify the prehistoric passages and allow an interpretation of the behaviour of visitors. All elements together form the picture of a family at a speleological investigation, which is attributed to the Mesolithic.
\end{abstract}

Keywords Mesolithic $\cdot$ Footprints $\cdot$ Torches $\cdot$ Lighting system $\cdot$ Karst

\section{Introduction}

Aldène Cave is located in the south of France in the heart of the Minervois plateau. This region is situated at the foot of the Montagne Noire, overlooking the vast Languedoc coastal plain that extends to the Mediterranean Sea. Administratively, this territory is in the Occitania region, straddling the departments of Aude and Hérault.

Ph. Galant $(\bowtie) \cdot$ P. Ambert ${ }^{\dagger} \cdot$ A. Colomer ${ }^{\dagger}$

Direction régionale des affaires culturelles Occitanie, Montpellier, France

e-mail: philippe.galant@culture.gouv.fr 
Fig. 15.1 Current view of the entrance to the first level of Aldène

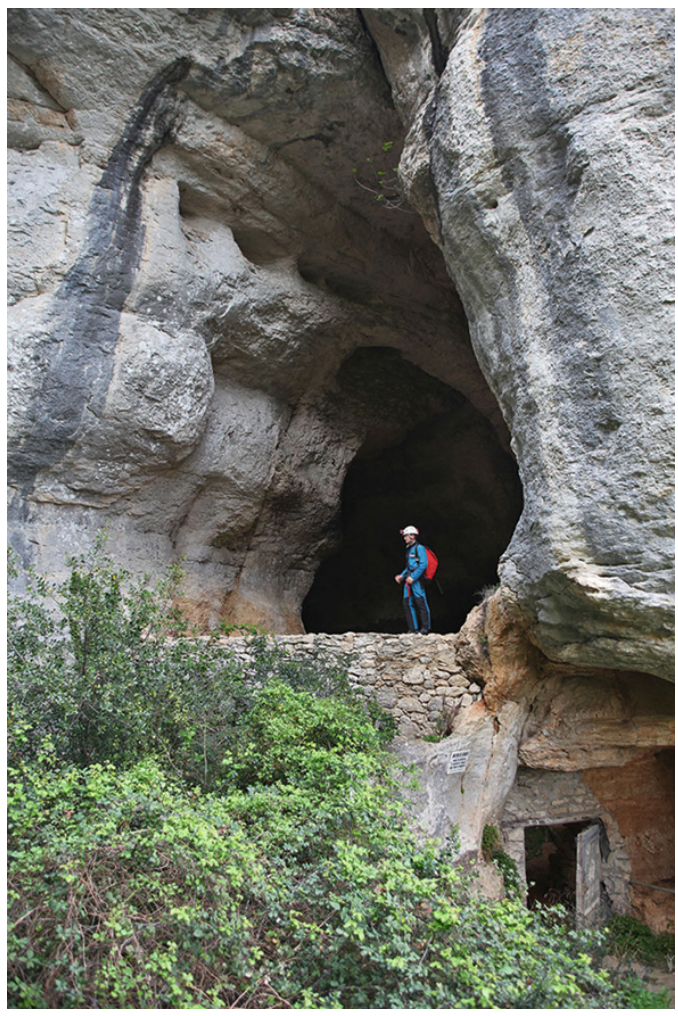

The cave opens to the gorge of the Cesse, a river that rises in the foothills of the Montagne Noire and flows south to join the Aude River. During the crossing of the limestone plateau of the Causses de Minerve, it cut deep gorges that revealed the entrance to Aldène. But much earlier, it is also this river that, before sinking into its canyon, shaped the subterranean network.

The cave is developed over more than $9 \mathrm{~km}$ of galleries which are spread over four different hydrogeological levels. The first two levels, of which the first is known since ever and the second discovered in 1948, are completely fossilized. The third level discovered in 1992 has a temporary flow during flood periods, while the fourth level found in 1994 constitutes part of the permanent subterranean course of the Cesse downstream of its first losses located at the Moulin de Monsieur at the beginning of the gorges.

This cave is known since ever. It has always been very popular for different interests: nature, archaeology, history, tourism, speleology, fauna, picturesque setting, emotions and many others (Fig. 15.1). It is a major site in the Minervois that its inhabitants have always known and frequented with continuity and often in a tradition of family tradition. It follows logically that Aldène, as it is locally called, in this region always triggers an interest, a curiosity for everything that happens there, for everything that concerns it. 


\section{A Major Natural Cave for the Heritage}

Aldène is the most important speleological network in the Minervois, and its speleological complex constitutes a subterranean drain in connection with the river Cesse. The galleries follow the natural slope of the surrounding rocks, towards the southwest and in the main directions of fracturing, which allows groundwater to reach the heart of the Aigne syncline and thus contribute to the constitution of the Cesse-Pouzols aquifer (Nou et al. 2013). The entire network is therefore integrated into this hydro-system and constitutes its main view of drainage and subterranean flows (Fig. 15.2).

The first level, known as the Bousquet level, has always been known as confirmed by the many archaeological remains that have been found there since the eighteenth century. Abbé Dominique Cathala discovered the second level, known as the Cathala level, in 1948. The third level, known as the René Azéma level, was discovered in 1992 by the speleologists of the Aldène Association. The same is true for the fourth level, known as the André network, discovered only in 1994 (Ambert 1998). The galleries that make up this network develop in the Eocene marine limestone of the tertiary era (known as alveolinous limestone), which rest in discordance on the Cambrian schisto-dolomitic series of the primary era. The corridors are cut in following regular fractures that give a very orthogonal appearance to the topography. Around main drains, many side connections become unexplored due to rocky barriers that prevent any passage. Several collapses also mark the ends of the main galleries.

The history of Aldène is very rich. In view of the many publications that recount this story, the researcher remains modest in the face of all these human, scientific and literary investments. Aldène has always intrigued passionate people without ever disappointing those who have been able to handle it. This cave has always had, locally but also regionally, a great scientific and tourist interest. This can be measured by the extensive bibliography concerning it. The census work currently being published by Yves Besset and Robert Marty reveals 700 references to books and articles relating to the cave (Besset and Marty forthcoming), more than a hundred of which were published before the twentieth century.

As early as 1776, Antoine-François de Gensanne published in his history of the province of Languedoc a very beautiful and complete description of the cave. At the very beginning of the nineteenth century, the paleontological interest of Aldène was recognized, in particular by the work of Marcel de Serres, who visited the site several times and identified many species following the discovery of fossil bones by his student Hyppolite Pittore. Throughout the nineteenth century, many publications, mainly for tourists, praised the beauty and interest of the cave. In particular, we can cite the text of Pierre Solomiac, known as Leg of Iron, a veteran who became a hermit of the cave and whose publication constitutes the very first tourist brochure on this cave (Solomiac 1885). He specialized in guiding visitors and has largely marked the history of the site with his legend. The greatest names of prehistory, a nascent science at the time, visited and wrote about Aldène. From 1880, the Narbonne 


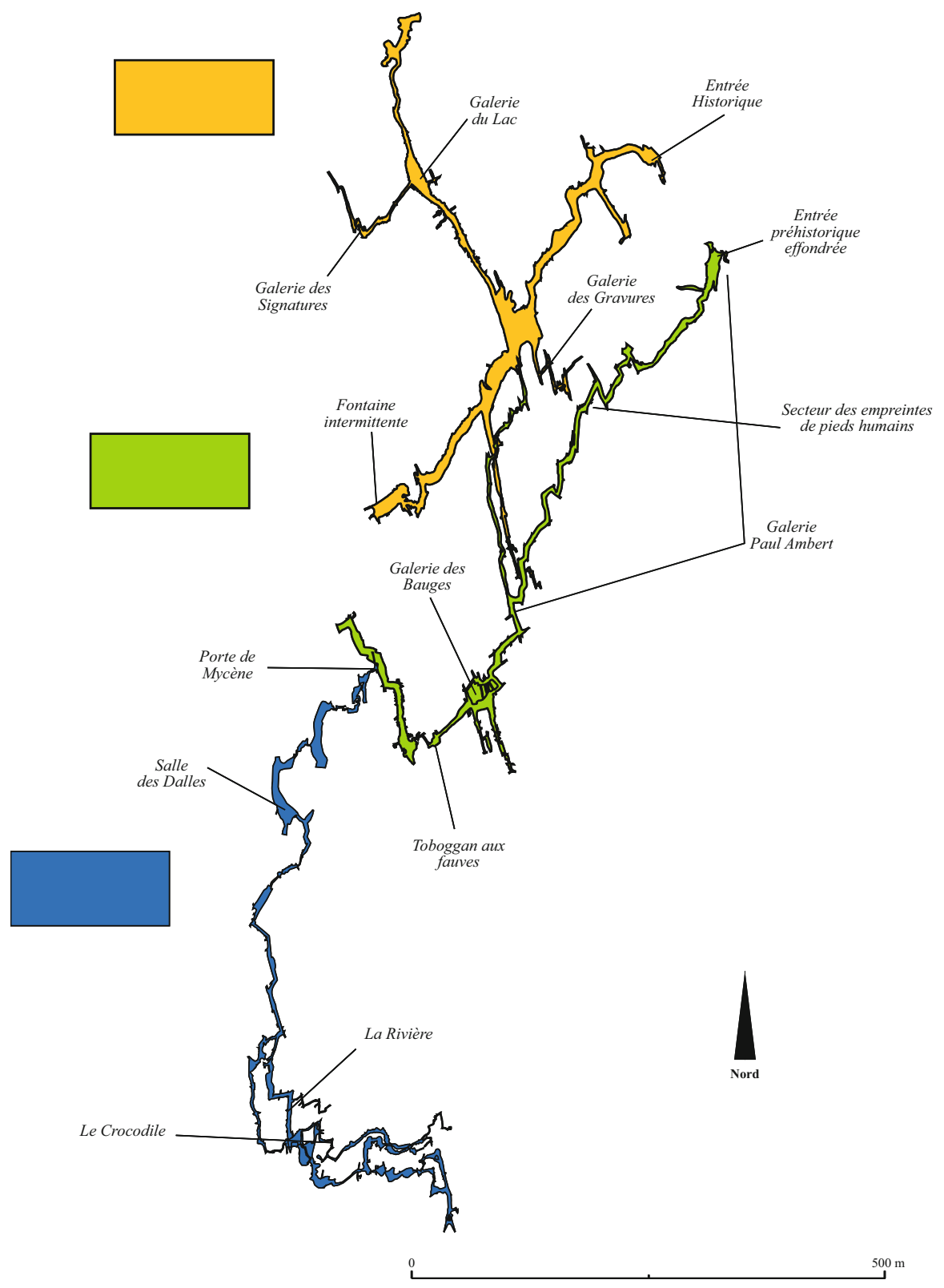

Fig. 15.2 Topographical survey of the first three levels of the cave and location of the main galleries (French Federation of Speleology - Technical UV instructor 1998)

geologist Armand Gautier identified the presence of lime and alumina phosphates in the cave and then called Minervite, which was in fact what researchers would later classify as guano-phosphates: the reaction between the large deposits of guanos due 
to the presence of bats and the clay fillings in the cave. This discovery led from 1888 to a systematic exploitation of the fillings on the first level, which, after many events, ended in 1943 in the field and with an administrative end in 1950. This exploitation was one of the most important for this type of substance in the whole Languedoc, even in the south of France. This work, which is estimated to have delivered 2840 tons of phosphates between 1888 and 1929, destroyed the paleontological stratifications that prevent the site from being studied forever (Gauchon 1997). Thus, almost all the archaeological and paleontological remains that had accumulated in these fillings over more than 400,000 years have disappeared! But what is contradictory is that this devastating exploitation has also allowed the discovery of remarkable remains that would have remained forever buried without it: in 1927 the gallery with Palaeolithic engravings (Guerret 1927) and in 1948 the access to the second level and the human paths (Cathala 1949). Throughout the exploitation, miners and other visitors collected various ancient objects that trace the prehistoric use of the cave. As an anecdote, noteworthy is the cave bear skull that was displayed in the office of the Director of Operations and was more than $1 \mathrm{~m}$ long, the tallest one Bernard Gèze had ever seen (Gèze 1994). Today, all these objects, which testify to the numerous Palaeolithic frequentations, the Neolithic, the Metal Ages, classical antiquity and the Middle Ages, are scattered throughout many private collections that remain unknown; only a few pieces are presented in the museums of Monaco, Montauban, Narbonne and Olonzac (Ambert and Galant 2007). From 1971 to 1998, the Museum of Prehistoric Anthropology of Monaco revealed, through the successive archaeological research of Louis Barral, Suzanne Simone and Patrick Simon, the chronostratigraphic Palaeolithic importance of the filling still preserved at the entrance to the cave. There is here a unique documentation for the knowledge of the frequentations of the entrance during the Lower Palaeolithic. The walls of the cave also contain many historical graffiti that remind us of the recurring visits since at least the Middle Ages and very importantly since the sixteenth century (Marty 2007). An object of curiosity, discovery and sensation, the cave has always been visited since then. This brief presentation of the heritage interests of the Aldène Cave allows us to argue that this cave has concealed for more than 400,000 years all the remains of the various human societies present in this region (Galant and Holwoet 2001). It can thus be classified as one of the most important archaeological sites in Europe.

\section{Exceptional Deposit Conditions}

The second level of the cave revealed, during its first exploration by Abbé Dominique Cathala (1899-1950) on first May 1948 (Fig. 15.3), very numerous palaeontological traces of bears and cave hyenas (dens, footprints, bones, claws) as well as exceptional archaeological remains in place: the path of human footprints and traces of torches. All these remains, present on the surface of the floors and walls, indicate the antiqueness and stability of the vestiges and the sedimentary structure in this part of the network. During the research program led by Paul Ambert 
Fig. 15.3 Abbé Dominique Cathala (left) discoverer of the second level of Aldène on May 1, 1948 and human footprints, accompanied (right) by Antoine Solenelle, the miner who showed him the blower hole on March 30, 1948. (Photo

N. Casteret, Daniel

André-Association Martel Collection)

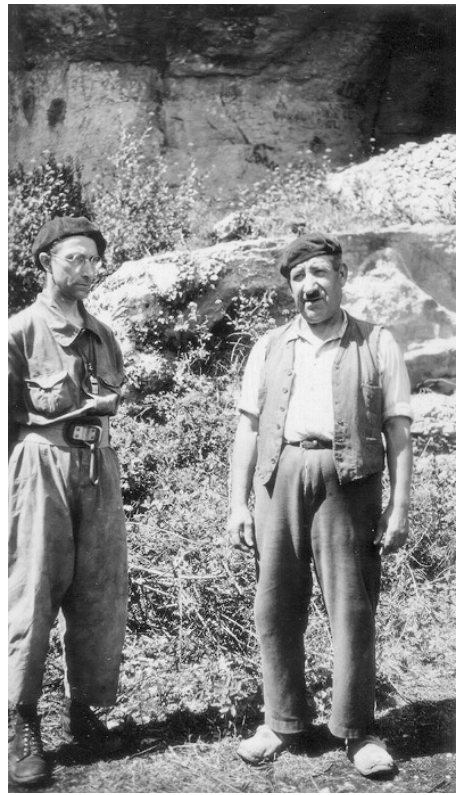

between 1996 and 2006, which aimed to date animal and human incursions into the Aldène network, a general geomorphological assessment was carried out (Ambert et al. 2000, 2005, 2007). This work made it possible to identify all the sedimentary dynamics of the cave network and their evolution over time (Ambert et al. 2010). In this scheme, the archaeological evidence had made it possible to establish the chronology of events for the most recent periods of the network's functioning. Thus, with regard to human footprints, it was possible to highlight the reasons for their conservation and, above all, the specificity of their situation in this part of the cave (Ambert et al. 2001).

For our part, we coordinated in this program the study of the traces of torches on the walls of the Galerie des Pas (Galant et al. 2007). This gallery, which extends over almost $700 \mathrm{~m}$, originated from the outside with an entrance that has now collapsed. The study of this passage, the only one that allowed access for animals and humans in this part of the network during prehistoric times, showed a slow evolution, to such an extent that when humans used it, the passage was lowered several tens of metres long before giving access to a large chamber extended by a vast and long gallery (Guendon et al. 2004). Inside, the traces of lighting on the floors and walls show that the gallery has been visited by humans for more than $500 \mathrm{~m}$. Our work made it possible to characterize the lighting system used (Fig. 15.4), to reproduce fairly accurately the passages used by humans on the way in and out of the cave and to understand the nature and origin of the traces of lighting still preserved. In addition, we were able to associate the lighting traces with the footprints, thus showing that this contemporaneity resulted from a single visit that corresponded to a speleological exploration of the network during the Mesolithic period. This characterization of a 
Fig. 15.4 Restitution of a prehistoric torch from the elements found on the floors and walls of Aldène. The device consists of about 15 juniper wood limbs that burn to produce a very good quality light

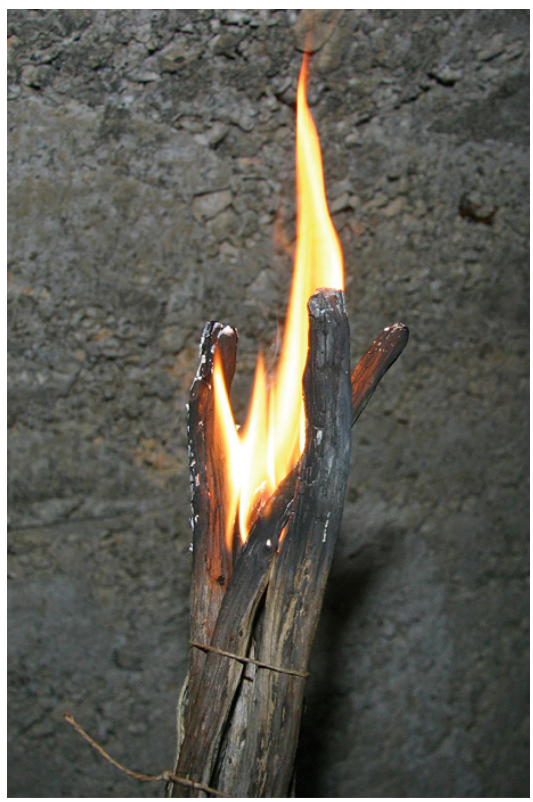

specific subterranean behaviour related to speleological exploration undermines the poorly documented theories put forward by some authors who have no reference or archaeological competence despite their claim to want to rewrite the course of history in this theme (Bigot 2010).

\section{A Problem of Complementary Study}

While working with the human footprints (Fig. 15.5a), we also had the chance to discover, outside the already known area, a new sector with about ten footprints. Today five sectors with human footprints are now known in this cave, among them the main path extending over about $30 \mathrm{~m}$. Due to the width of the gallery, the footprints of the main path can only be seen from the gateway that borders it laterally. To date no supporting document has been available to inventory or work on these traces. We were then satisfied with making simple visual observations. Thus, we estimated that the human group from which these traces originated was composed of about 20 people, mostly children accompanied by only a few adults. This group only made one round trip through the gallery which allowed us to study the traces of torches as contemporaneous phenomena (Fig. 15.5b). This is the first time that such observations were made in a cave on such remains.

With hindsight, we can now say that this project has remained unfinished. It seems important to us to document with new and reliable methods the relationship between the human paths and the parietal traces present on the walls as one of the 
Fig. 15.5 (a) Detail of a human footprint of the sector $\mathrm{C}$ path well marked in the clay that forms the floor of the gallery; (b) human footprints on the path in sector C. These tracks, which go in different directions, clearly indicate the prehistoric group's round trip
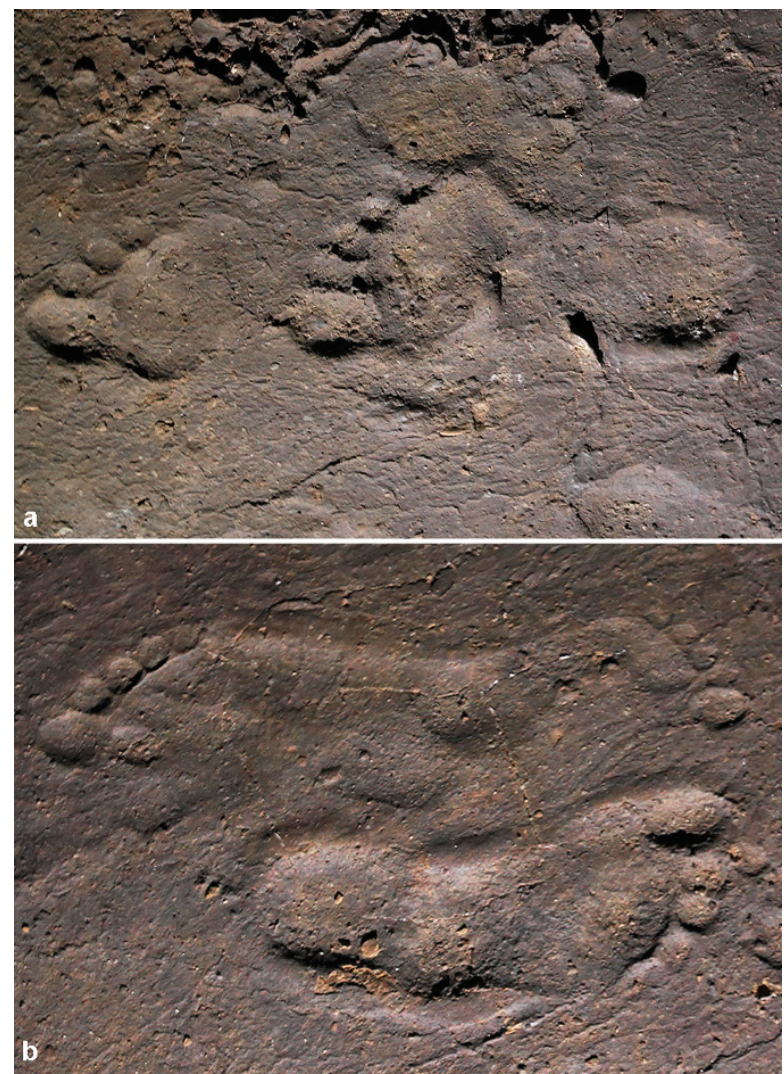

main research interests. On the other hand, it also seems essential to us to better characterize the composition of the human group that carried out this speleological exploration more than 8000 years ago, our first assessment being too subjective. To do this, a more precise diagnosis of the footprints must be made. A comprehensive and complete inventory must be drawn up based on a global survey of the five sectors with human footprints known to date. This inventory must also allow to identify each track individually, to carry out biometric measurements in the hope of being able to characterize the stature and age of the trackmaker but also to try to consider a diagnosis of sex. The aim is to characterize the composition of the group as detailed as possible. It will be also important to try to identify and associate the footprints of the same subject in order to be able to define the step sequences and thus to try to approach human behaviour in the cave. These data will be complementary to all those already acquired. 


\section{The Contribution of the Traces of Torches}

The human presence in the Cathala level of Aldène is also evinced by the presence of charcoal traces on the walls. Just after the discovery in 1948, these remains were interpreted as torch smears, and about 30 of these traces had been inventoried. The completion of a new systematic inventory based on a detailed examination of the floors and walls enabled us to identify 105 points related to lighting management during the prehistoric visit (Galant et al. 2007). These traces are present at the entrance to the cave network where a profusion of layers of charcoal is visible on the floor (Fig. 15.6). The experiments carried out within the framework of this study had revealed that this corresponded well to the lighting of the torches with the thin parts of fire sticks which burn down very fast. The traces found on the walls throughout the rest of the subterranean path could be divided into two types: accidental traces corresponding to unintentional impacts of the lighting systems under particular conditions related to the morphology of the network and advance (Fig. 15.7a) and voluntary traces, always preceded by impacts on the wall to break the longest ends of the torches and thus make a mark during the visit (Fig. 15.7b). Accidental traces generally correspond to lateral friction of the torches, leaving a very characteristic mark on the walls. On the contrary, the voluntary traces correspond to crushing of the end of the torch perpendicular to the wall. These two types of traces are very different.

More than $500 \mathrm{~m}$ from the entrance, a final voluntary trace of a torch on the wall seems to indicate the end point of this prehistoric visit to the cave. We then questioned the reasons for this interruption of the presence of traces further into the network, because this point constitutes a stop on nothing and the gallery still extends over vast proportions and a great distance: no natural obstacle hinders the progression at this level. Detailed examination of the walls beyond this passage revealed no trace of a torch; similarly, no charcoal remains or human footprints were seen on the floor. Observation of the geomorphological conditions of this part of the cave network also informs us that there is no reason for differential conservation of these types of remains. Their absence is therefore well linked to an act of omission. Can we then think that the prehistoric visitors of the network continued their visit without leaving a trace on the floors and walls? All the remains observed since the entrance to the network and over the first $500 \mathrm{~m}$ invalidate this hypothesis, because the conditions of the galleries in the rest of the network are similar and the observation of the nature and distribution of the traces in the area frequented indicates that we should have found some if prehistoric exploration had extended beyond this point. This last trace of a torch therefore corresponds well to the end of the prehistoric visit. So how to explain this end, when there is no commitment from a speleological point of view to stop the progression at this point of the network. The most probable hypothesis seems to us to be the one that is called in speleology a stop on autonomy. Indeed, it seems obvious that to embark on this exploration, visitors had to bring a certain number of torches necessary for the production of light. It is therefore easy to imagine that at this point, if they had consumed no more than half 


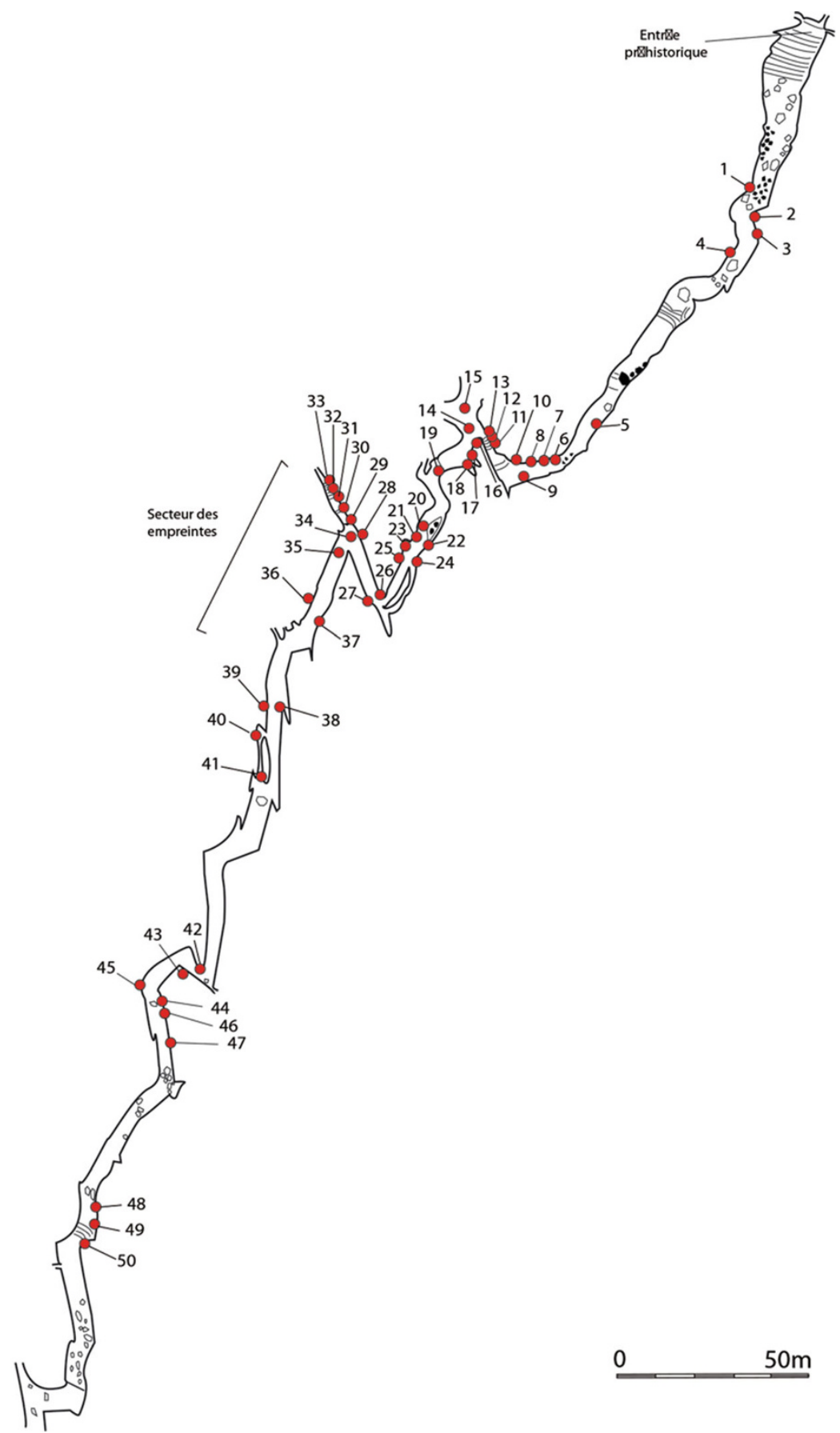

Fig. 15.6 Distribution plan of the different traces of torches found, indicating the area explored by prehistoric speleologists 
Fig. 15.7 (a) Unintentional trace of a torch corresponding to a lateral friction of the lighting device. This type of vestige makes it possible to accurately reproduce the prehistoric path within the gallery; (b) voluntary trace of a torch, marked by an impact perpendicular to the wall. This element seems to correspond to a marking element
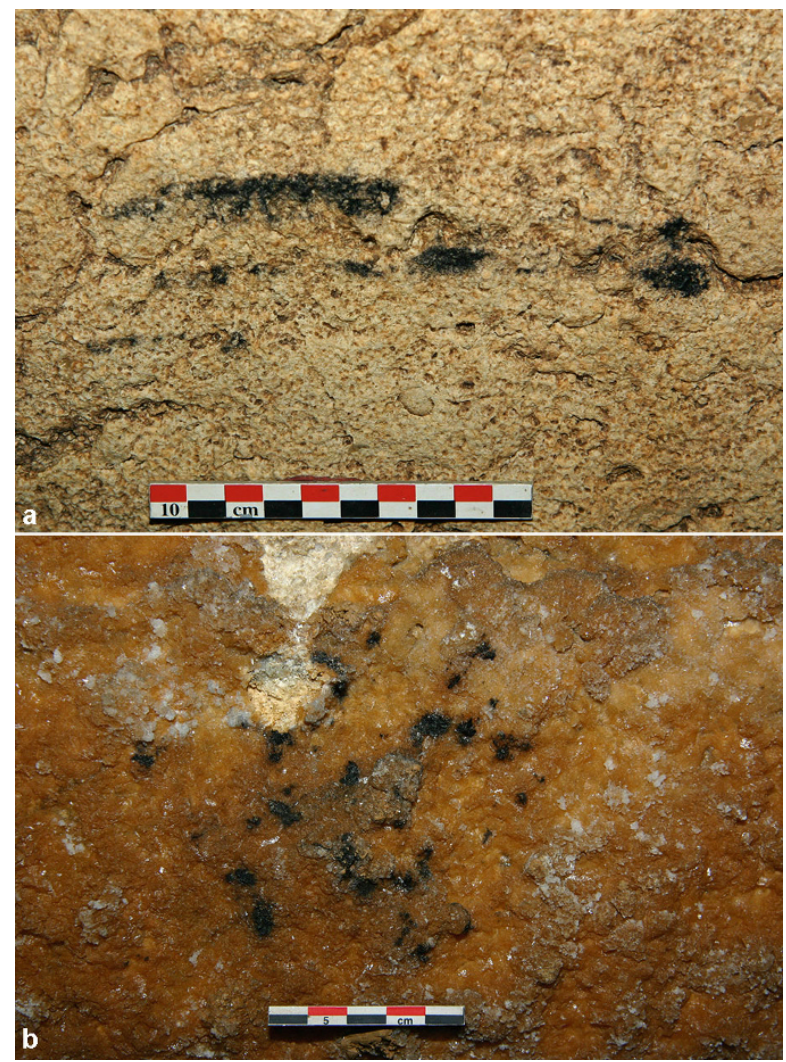

of their reserve, they would have thought of returning, light being crucial, even vital, in this kind of exercise. We therefore have here the very ancient testimonies of a prehistoric speleological exploration that has the same behavioural characteristics as those of current speleologists.

\section{Human Footprints}

These traces are distributed in a very limited part of the total space covered in the cave by the human group during the Mesolithic period. It is estimated that only $10 \%$ of the path taken is still partially marked by human footprints. This is due to two main phenomena: footprints are only marked if there is a passage on a plastic surface; after execution, the preservation conditions must allow the tracks to be kept in place. In the particular case of Aldène, it can be estimated that 40-50\% of the substrate of the prehistoric paths could be appropriate for leaving tracks. This situation suggests that many traces have disappeared. This disappearance is mainly due to three reasons: there is a lateral water inflow into the gallery that has partially 
incised the clay filling superficially; this same water inflow and other flow sources have generated a partial hydrological loading of the galleries, a phenomenon that has resulted in a surface clay-silt inflow that has partially covered the clay floors; and the use of the network since its discovery in 1948 has resulted in extensive trampling of areas that may have borne human footprints. It can also be assumed that in a very specific way, other taphonomic phenomena have altered the conservation of footprints (falling stillation water from the vault, falling blocks, calcifications on the floor, trampling after the discovery, etc.).

These situations explain why human footprints are concentrated at several points over only about $50 \mathrm{~m}$. In this space, five sectors can be identified that show human footprints. These sectors are classified in succession according to the current access to the gallery, i.e. by moving from inside the network to the prehistoric entrance which is currently blocked.

- Sector A: This is the newly discovered complex and the southernmost of all the footprints. They develop over a $4.4 \mathrm{~m}$ long space with an average width of $1.1 \mathrm{~m}$. This area, where the original floors have been preserved despite modern circulation since the discovery, is located at the foot of the wall. It consists of a ninefootprint trackway on the east side of the gallery. On the other side of the gallery, to the west, there is a probable isolated footprint that remains to be confirmed and the suspicion of other faint spoors. These spoors were discovered on September 12, 2006 during the study of the traces of torches. They had not been seen during the discovery and owe their preservation only to a recent way marking (1994) put in place to prevent the trampling caused by current visits from spreading throughout the gallery.

- Sector B: This is a small set of poorly identified footprints in an old, very liquid clay puddle that is now dry and partially hardened, covering an area of $2 \times 2.7 \mathrm{~m}$. It is assumed that several tracks are present but remain very difficult to see. This sector is located just before the main path in the interior that forms the corner of the gallery to the southeast. It had been noticed upon the discovery and is protected by the installation of a railing.

- Sector C: This is the main human footprints path that occupies an entire section of the gallery oriented on a southwest-northeast axis (Fig. 15.8a). It covers an area of about $3 \mathrm{~m}$ wide and about $30 \mathrm{~m}$ long. Abbé Dominique Cathala had found almost 200 human footprints on its surface, but due to superimpositions, it would appear that this number must be much higher (Fig. 15.8b). Léon Pales has identified more than 300 footprints, and for our part, we estimate that the final result of the inventory will be closer to 400 footprints! However, this surface shows several areas without footprints for taphonomic reasons due to the normal functioning of the cave. The entire northern part of this path is partially covered by a stalagmitic floor that has also sealed human footprints which remain difficult to identify.

- Sector D: It is located on the same axis as the previous sector and only less than $1 \mathrm{~m}$ from its northeast end. It is a former dry sinter basin that was crossed by part of the prehistoric visitor group (Fig. 15.9). This area, measuring approximately $1.3 \times 2.4 \mathrm{~m}$, contains less than ten human footprints; they have the particularity 
Fig. 15.8 (a) General view of sector C, taken from the southwest to the northeast; (b) concentration of human footprints in sector $\mathrm{C}$ (main path about $30 \mathrm{~m}$ long)
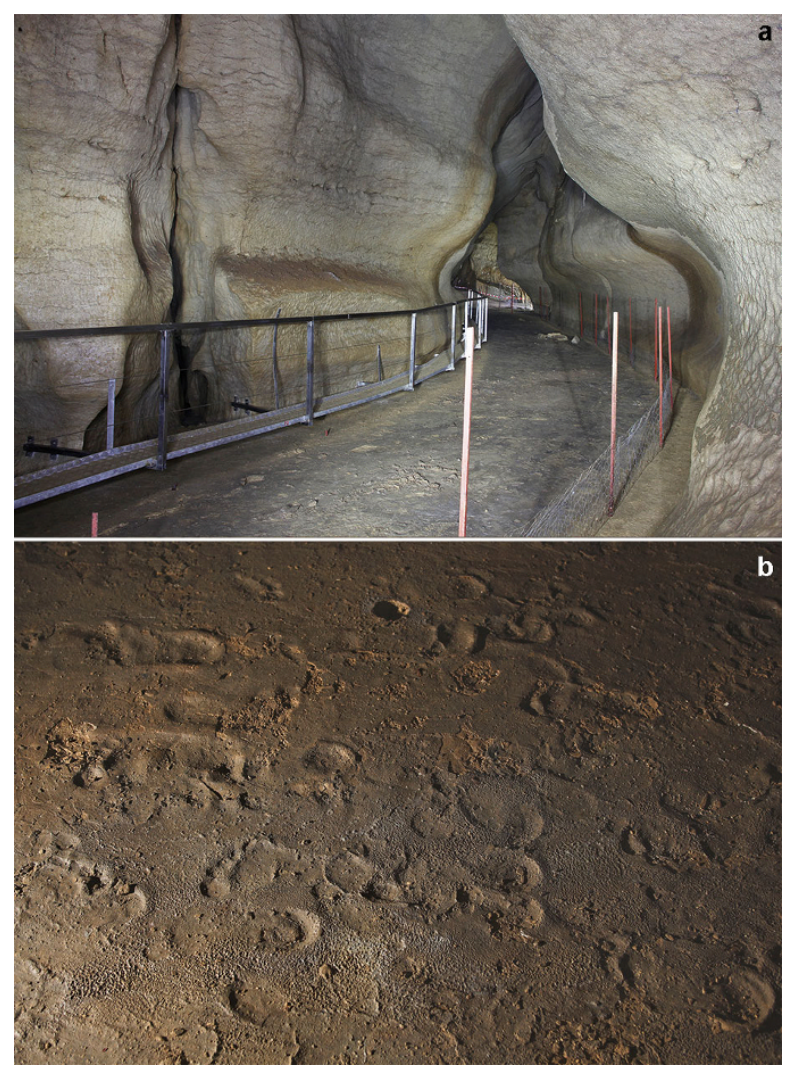

of being accompanied by two traces of sticks dragged through the clay in direct relation to the footprints.

- Sector E: This is the start of the gallery that opens in front of the previous sector to the left and north end of sector C. It seems that the group of prehistoric visitors entered this gallery, at the highest level of its vault, through an elongated sinter basin filled with fairly liquid clay. The floor is now totally calcified, freezing the footprints (Fig. 15.10). Many footprints are visible, more than 50 of them, in a space very constrained by the morphology of the passage which forms a surface of $1.5 \times 2.8 \mathrm{~m}$.

- Sector F: This footprint sector is the most remote in the network. It does not have a human footprint as such. The passage between the two ancient lakes shows a height of about $0.6-0.8 \mathrm{~m}$. Bear paw prints, a human handprint and traces that can correspond to human knees can be found punctually on an area of about $10 \mathrm{~m}^{2}$. 


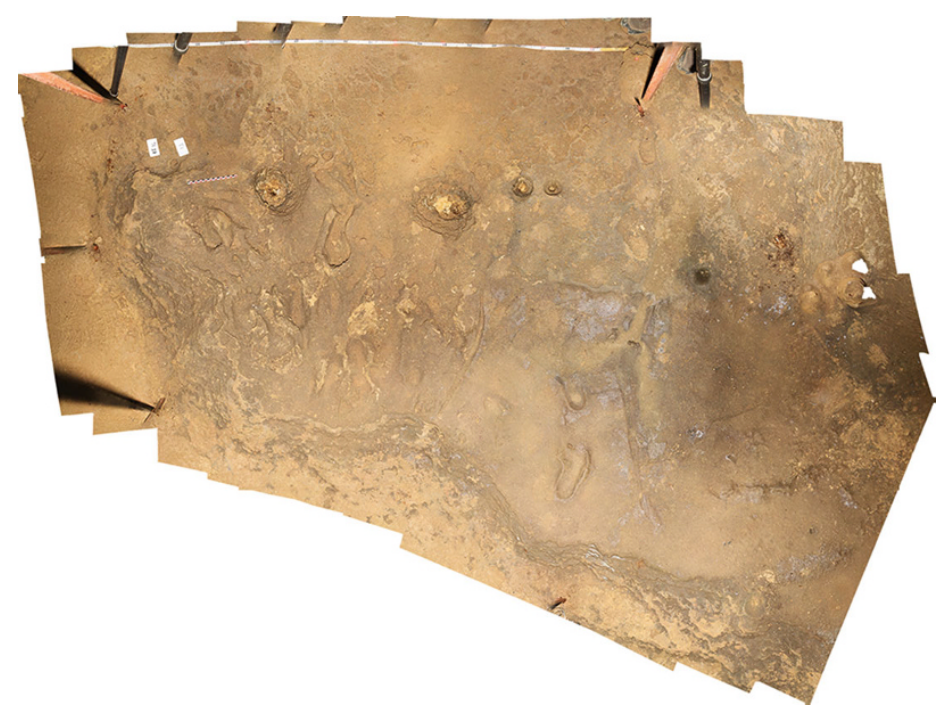

Fig. 15.9 Orthophotography of sector D generated from the photogrammetric survey

\section{The Study of the Human Footprints of the Paul Ambert Gallery}

The study of the human footprints of the Paul Ambert gallery in Aldène has never really been carried out since the site was discovered in 1948. The analysis begun by Abbé Dominique Cathala after his discovery of the network was not completed following his untimely death. It was only partially presented and then published by his sister at the first International Congress of Speleology (Cathala 1953).

Between 1952 and 1954, several members of the Société Méridionale de Spéléologie et de Préhistoire de Toulouse (SMSP), under the direction of Marguerite Cathala, carried out topographical surveys of the two levels then known in the cave. Similarly, they continued the analysis of the footprints from the main path (sector $\mathrm{C}$ in our classification) from the one initially studied by Abbé Dominique Cathala before his death. This work was carried out on the basis of the grid that Louis Méroc had advised Abbé Dominique Cathala to draw on the floor. In addition to the historical and documentary aspects of these surveys, the complete and detailed history of Abbé Dominique Cathala's discovery of the second level is given. To our knowledge, this is the only document that mentions these facts.

In 1973 and 1974, a study mission on these tracks was carried out under the direction of Léon Pales (1908-1988). These works, which have not been published, are only indicated by brief information in a notice of the site in the atlas of the decorated caves (Pales and Vialou 1984). According to this, copies of part of the main path were made by Michel-Alain Garcia, which are now in the Musée National de Préhistoire des Eyzies-de-Tayac-Sireuil (Dordogne). In addition to the copies, the 


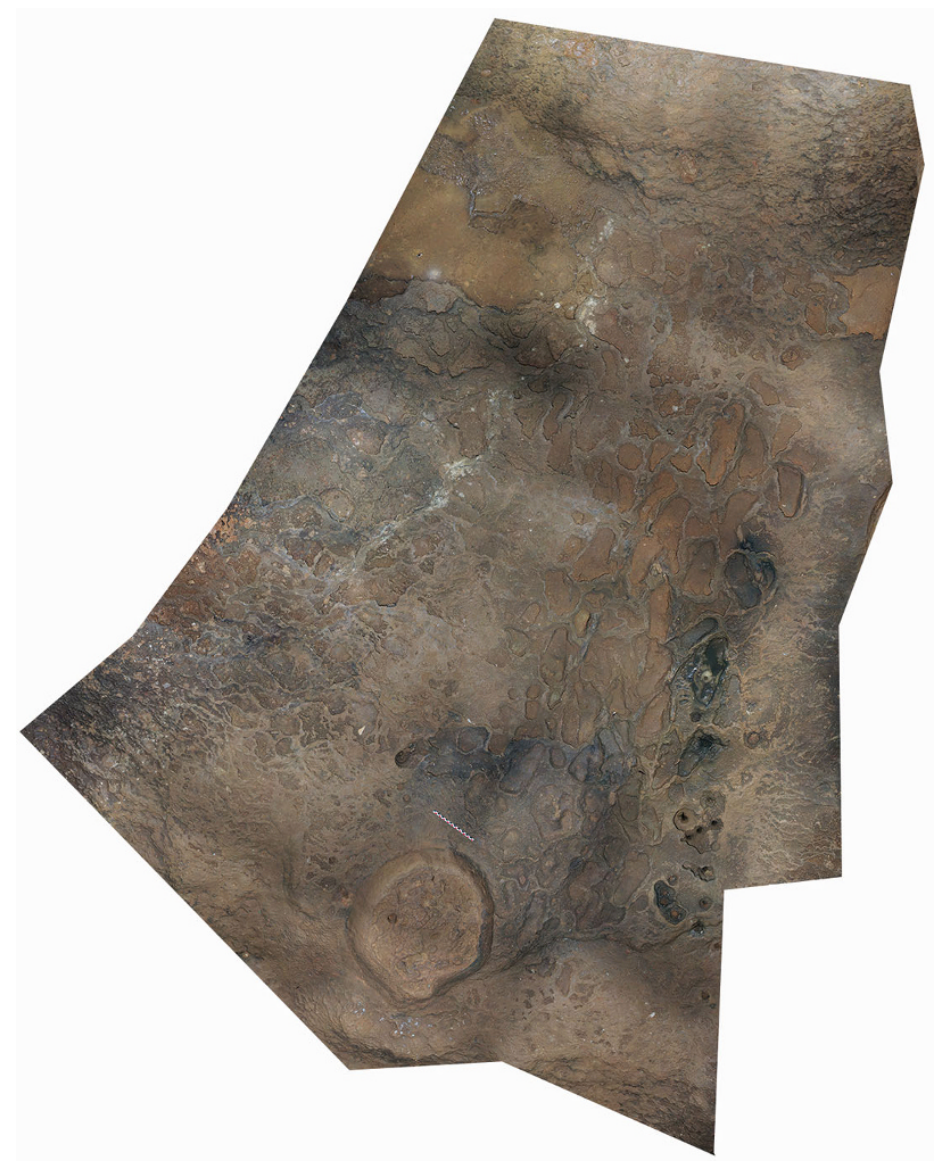

Fig. 15.10 Orthophotography of sector E generated from the photogrammetric survey

museum houses Léon Pales' personal archives, and it is likely that they contain other important documents about his work in Aldène.

\section{A New Research Program}

Faced with the lack of an exhaustive study of heritage remains as important as those present in terms of ichnology in Aldène (by their nature, quantity, quality, chronology), we have embarked on new research on this site. This work was initiated on the basis of the three-dimensional digitization of floors with human footprints carried out in collaboration with the Société Géomesure, the IUT de Nîmes for the scanning part and with Thierry Montécinos for the photogrammetric survey. The principle of an exhaustive inventory of all traces has been put in place through the definition of 
several criteria to be recorded on each footprint. This project will also address the biometric and paleoanthropological study of traces thanks to the collaboration with Henri Duday (PACEA laboratory). A large-scale experimentation project is also planned under the responsibility of Jean-Louis Orengo, founder of a theme park on ichnology named "Au Pays des Traces" ("In the land of tracks", Ariège, France). Furthermore, the footprints of various sectors were examined by three indigenous ichnologists from Namibia (Thui Thao, /Ui Kxunta and Tsamgoa Ciqae) as part of a week-long campaign. This extraordinary visit was made possible by cooperation with the Tracking in Caves project (see Lenssen-Erz and Pastoors Chap. 6). This study project will therefore allow a comprehensive scientific approach to the footprints of Aldène. The progress of research in the field of prehistory therefore encourages us to perceive differently the remains that we thought we were studying. The new techniques made available to researchers are renewing the reading of the archaeological data still in place. The first results of this research already allow us to consider rather surprising results that will most certainly allow us to rethink the relationship between humans and the subterranean sphere during prehistory.

\section{References}

Ambert, P. (1998). La grotte d'Aldène (La Coquille, Grotte de Fauzan) à Cesseras, Hérault: son contexte géologique et archéologique. Olonzac: Centre de Recherche et de Documentation du Minervois.

Ambert, P., \& Galant, P. (2007). La préhistoire récente de la grotte d'Aldène. Bulletin du Musée d'Anthropologie Préhistorique de Monaco, 47, 81-100.

Ambert, P., Colomer, A., \& Galant, P. (2000). Datations mésolithiques des empreintes humaines de l'étage Cathala de la grotte d'Aldène (Cesseras, Hérault). Paléovol, Comptes rendus de l'Académie des Sciences de Paris, 331, 67-74.

Ambert, P., Galant, P., \& Colomer, A. (2001). Incursions spéléologiques mésolithiques dans la grotte d'Aldène (Cesseras, Hérault). Bulletin de la Société Préhistorique Française, 98(3), 497-503.

Ambert, P., Guendon, J.-L., Galant, P., Quinif, Y., Gruneisen, A., Colomer, A., Dainat, D., Beaumes, B., \& Requirand, C. (2005). Attribution des gravures paléolithiques de la grotte d'Aldène (Cesseras, Hérault) à l'Aurignacien par la datation des remplissages géologiques. Paléovol, Compte rendu de l'Académie des Sciences de Paris, 4(3), 275-284.

Ambert, P., Galant, P., Guendon, J.-L., \& Colomer, A. (2007). Les gravures et les empreintes humaines de la grotte d'Aldène (Cesseras, Hérault), dans leur contexte chronologique et culturel. Bulletin du Musée d'Anthropologie Préhistorique de Monaco, 47, 3-36.

Ambert, P., Colomer, A., \& Galant, P.H. (2010). Percevoir autrement la préhistoire de la grotte d'Aldène (Cesseras, Hérault). In P. Audra (Ed). Grottes et Karst de France (pp. 100-101), Karstologia Mémoires, 19. Nîmes: Association Française de Karstologie.

Besset, Y., \& Marty, R. (forthcoming). Sur les Traces de l'Aldène: essai de bibliographie et d'histoire. Cesseras: Association Aldène et Association Minervoise d'Explorations Spéléologiques.

Bigot, J.-Y. (2010). Histoire des incursions souterraines en France. In P. Audra (dir). Grottes et Karst de France (pp. 102-103), Karstologia Mémoires, 19. Nîmes: Association Française de Karstologie. 
Cathala, D. (1949). Découvertes en 1948 dans la grotte d'Aldène (Hérault). Bulletin de la Société Méridionale de Spéléologie et de Préhistoire, 84, 209-214.

Cathala, M. (1953). Découvertes préhistoriques dans la grotte d'Aldène-Minerve, Cesseras (Hérault). Actes du premier congrès international de spéléologie, Paris, IV(4), 53-62.

Galant, P., \& Holwoet, J.-P. (2001). La grotte d'Aldène à Cesseras (Hérault). Spélunca, 81, 23-35.

Galant, P., Ambert, P., Colomer, A., \& Guendon, J.-L. (2007). Les vestiges d'éclairages préhistoriques de la galerie des Pas de la grotte d'Aldène (Cesseras, Hérault). Bulletin $d u$ Musée d'Anthropologie Préhistorique de Monaco, 47, 37-80.

Gauchon, C.H. (1997). Des cavernes et des hommes: Géographie souterraine des montagnes françaises. Karstologia mémoire, 7. Nîmes: Association Française de Karstologie.

Gèze, B. (1994). La ruée vers le phosphate dans les cavernes du midi de la France. Travaux du Comité français d'histoire de la géologie, VIII(3), 9-12.

Guendon, J.-L., Ambert, P., Quinif, Y., Beaumes, B., Colomer, A., Dainat, D., Galant, P., Gruneisen, A., \& Gruneisen, N. (2004). Âges et modalités des incursions humaines et animales préhistoriques dans l'étage Cathala de la grotte d'Aldène (Hérault, France). Karstologia, 43, $27-38$.

Guerret, M. (1927). Découverte de dessins préhistoriques dans la grotte d'Aldène. Bulletin de la Société Préhistorique Française, LVI, 318-324.

Marty, R. (2007). Les graffitis de la grotte d'Aldène à Cesseras (34). Généalogie en Minervois, 67, $13-19$.

Nou, A., Pistre, S., Batiot-Guilhe, C., \& Borrell-Estupina, V. (2013). Évolution hydrogéologique de l'hydrosystème karstique Cesse-Pouzols (Minervois, France) au cours du quaternaire. Quaternaire, Revue de l'Association française pour l'étude du quaternaire, 24(1), 25-34.

Pales, L., \& Vialou, D. (1984). Grotte de l'Aldène. In L'art des cavernes: Atlas des grottes ornées Paléolithiques françaises (pp. 340-342). Paris: Ministère de la Culture et de la Communication, Imprimerie Nationale.

Solomiac, P. (1885). Description de la grotte de la Coquille ou d'Aldène près Cesseras (Hérault), improprement appelée Grotte de Minerve. Carcassone: Éditions Grande imprimerie.

Open Access This chapter is licensed under the terms of the Creative Commons Attribution 4.0 International License (http://creativecommons.org/licenses/by/4.0/), which permits use, sharing, adaptation, distribution and reproduction in any medium or format, as long as you give appropriate credit to the original author(s) and the source, provide a link to the Creative Commons license and indicate if changes were made.

The images or other third party material in this chapter are included in the chapter's Creative Commons license, unless indicated otherwise in a credit line to the material. If material is not included in the chapter's Creative Commons license and your intended use is not permitted by statutory regulation or exceeds the permitted use, you will need to obtain permission directly from the copyright holder.

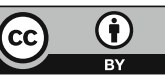

